\title{
Front Matter: Volume 9308
}

, "Front Matter: Volume 9308," Proc. SPIE 9308, Optical Methods for Tumor Treatment and Detection: Mechanisms and Techniques in Photodynamic Therapy XXIV, 930801 (25 March 2015); doi: 10.1117/12.2183912

SPIE. Event: SPIE BiOS, 2015, San Francisco, California, United States 


\title{
PROGRESS IN BIOMEDICAL OPTICS AND IMAGING

\section{Optical Methods for Tumor Treatment and Detection: Mechanisms and Techniques in Photodynamic Therapy XXIV}

\author{
David H. Kessel \\ Tayyaba Hasan \\ Editors
}

7-9 February 2015

San Francisco, California, United States

Sponsored and Published by

SPIE 
The papers included in this volume were part of the technical conference cited on the cover and title page. Papers were selected and subject to review by the editors and conference program committee. Some conference presentations may not be available for publication. The papers published in these proceedings reflect the work and thoughts of the authors and are published herein as submitted. The publisher is not responsible for the validity of the information or for any outcomes resulting from reliance thereon.

Please use the following format to cite material from this book:

Author(s), "Title of Paper," in Optical Methods for Tumor Treatment and Detection: Mechanisms and Techniques in Photodynamic Therapy XXIV, edited by David H. Kessel, Tayyaba Hasan, Proceedings of SPIE Vol. 9308 (SPIE, Bellingham, WA, 2015) Article CID Number.

ISSN: 1605-7422

ISBN: 9781628413984

Published by

SPIE

P.O. Box 10, Bellingham, Washington 98227-0010 USA

Telephone +1 3606763290 (Pacific Time) · Fax +1 3606471445

SPIE.org

Copyright (c) 2015, Society of Photo-Optical Instrumentation Engineers.

Copying of material in this book for internal or personal use, or for the internal or personal use of specific clients, beyond the fair use provisions granted by the U.S. Copyright Law is authorized by SPIE subject to payment of copying fees. The Transactional Reporting Service base fee for this volume is $\$ 18.00$ per article (or portion thereof), which should be paid directly to the Copyright Clearance Center (CCC), 222 Rosewood Drive, Danvers, MA 01923. Payment may also be made electronically through CCC Online at copyright.com. Other copying for republication, resale, advertising or promotion, or any form of systematic or multiple reproduction of any material in this book is prohibited except with permission in writing from the publisher. The CCC fee code is $1605-7422 / 15 / \$ 18.00$.

Printed in the United States of America.

Publication of record for individual papers is online in the SPIE Digital Library.

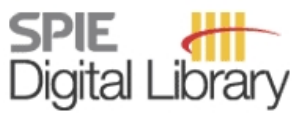

SPIEDigitalLibrary.org

Paper Numbering: Proceedings of SPIE follow an e-First publication model, with papers published first online and then in print. Papers are published as they are submitted and meet publication criteria. A unique citation identifier (CID) number is assigned to each article at the time of the first publication. Utilization of CIDs allows articles to be fully citable as soon as they are published online, and connects the same identifier to all online, print, and electronic versions of the publication. SPIE uses a six-digit CID article numbering system in which:

- The first four digits correspond to the SPIE volume number.

- The last two digits indicate publication order within the volume using a Base 36 numbering

system employing both numerals and letters. These two-number sets start with 00, 01, 02, 03, 04, $05,06,07,08,09,0 A, 0 B \ldots$. OZ, followed by 10-1Z, 20-2Z, etc.

The CID Number appears on each page of the manuscript. The complete citation is used on the first page, and an abbreviated version on subsequent pages. 


\title{
Contents
}

\author{
$\checkmark \quad$ Authors \\ vii Conference Committee \\ ix Introduction
}

PHOTODYNAMIC THERAPY I

930802 Promotion of PDT efficacy by low-dose lysosomal photodamage (Invited Paper) [9308-1]

PHOTODYNAMIC THERAPY III

930809 Real-time treatment light dose guidance of Pleural PDT: an update [9308-8]

9308 OA In vivo outcome study of BPD-mediated PDT using a macroscopic singlet oxygen model [9308-9]

NIH REPORT

$9308 \mathrm{OE} \quad \mathrm{NIH}$ and NCl grant-related changes during fiscal years 2014 and 2015 (Invited Paper) [9308-14]

PHOTODYNAMIC THERAPY V

$9308 \mathrm{OH} \quad$ Clinical potential for vitamin D as a neoadjuvant for photodynamic therapy of nonmelanoma skin cancer (Invited Paper) [9308-17]

\section{PHOTODYNAMIC THERAPY VI}

9308 0J Use of cylindrical diffusing fibers as detectors for interstitial tissue spectroscopy [9308-19]

9308 OK Effects of verteporfin-mediated photodynamic therapy on endothelial cells [9308-20]

9308 OL Block copolymers encapsulated poly (aryl benzyl ether) dendrimer silicon (IV) phthalocyanine for in vivo and in vitro photodynamic efficacy of choroidal neovascularization [9308-21] 
9308 ON In-vivo outcome study of HPPH mediated PDT using singlet oxygen explicit dosimetry (SOED) [9308-23]

930800 Monte Carlo fluence simulation for prospective evaluation of interstitial photodynamic therapy treatment plans [9308-24]

\section{PHOTODYNAMIC THERAPY VIII}

$93080 Q$ Topical calcitriol prior to photodynamic therapy enhances treatment efficacy in nonmelanoma skin cancer mouse models [9308-26]

9308 OR Crystalline organic nanoparticles for diagnosis and PDT [9308-27]

9308 OT An empirical approach to estimate near-infra-red photon propagation and optically induced drug release in brain tissues [9308-29]

\section{POSTER SESSION}

9308 OU Photoinduced electron transfer between the dendritic zinc phthalocyanines and anthraquinone [9308-33]

9308 OV Macroscopic singlet oxygen model incorporating photobleaching as an input parameter [9308-34]

9308 0X Photodynamic therapy application of PAMAM-porphyrin molecule on stomach cancer cells [9308-39]

930811 Early photosensitizer uptake kinetics predict optimum drug-light interval for photodynamic therapy [9308-32]

930812 Characterization of rare-earth-doped nanophosphors for photodynamic therapy excited by clinical ionizing radiation beams [9308-35]

930813 In vivo suppression of solid Ehrlich cancer via chlorophyllin derivative mediated PDT: an albino mouse tumour model [9308-36]

930814 Photodynamic therapy using hemagglutinating virus of Japan envelope (HVJ-E): a novel therapeutic approach for the treatment of hormone antagonistic prostate cancer [9308-37] 


\section{Authors}

Numbers in the index correspond to the last two digits of the six-digit citation identifier (CID) article numbering system used in Proceedings of SPIE. The first four digits reflect the volume number. Base 36 numbering is employed for the last two digits and indicates the order of articles within the volume. Numbers start with 00, 01, 02, 03, 04, 05, 06, 07, 08, 09, 0A, 0B...0Z, followed by 10-1Z, 20-2Z, etc.

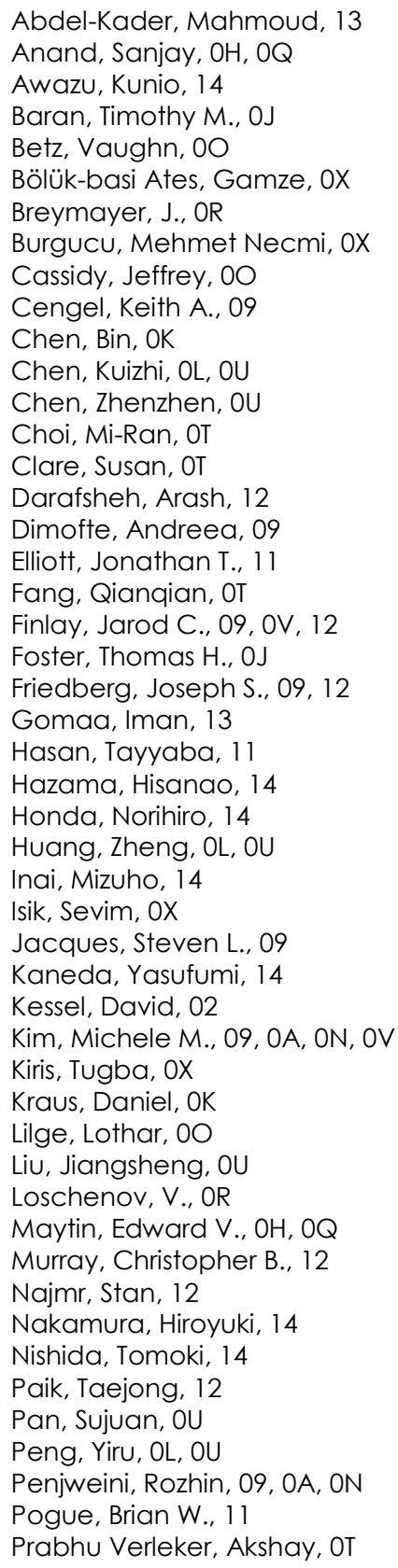

\author{
Rollakanti, Kishore, $\mathrm{OH}, \mathrm{OQ}$ \\ Rück, A., OR \\ Ryabova, A., OR \\ Sagir, Tugba, OX \\ Samkoe, Kimberley S., 11 \\ Saraya, Hend, 13 \\ Senel, Mehmet, OX \\ Simone, Charles B., II, 09 \\ Sinha, Lagnojita, 11 \\ Stantz, Keith M., OT \\ Steiner, R., OR \\ Tabakoglu, Hasim Ozgur, OX \\ Tachikawa, Shoji, 14 \\ Tenuto, Michael E., 12 \\ Tichaver, Kenneth M., 11 \\ Wang, Xiongwei, OL \\ Wen, Junri, OU \\ Wong, Rosemary S. L., OE \\ Yamauchi, Masaya, 14 \\ Yasuda, Hidehiro, 14 \\ Zekri, Maha, 13 \\ Zhu, Timothy C., 09, OA, ON, OV
}


Proc. of SPIE Vol. $9308930801-6$

Downloaded From: https://www.spiedigitallibrary.org/conference-proceedings-of-spie on 26 Apr 2023 Terms of Use: https://www.spiedigitallibrary.org/terms-of-use 


\title{
Conference Committee
}

\author{
Symposium Chairs
}

James G. Fujimoto, Massachusetts Institute of Technology

(United States)

R. Rox Anderson, Wellman Center for Photomedicine, Massachusetts General Hospital (United States) and Harvard School of Medicine (United States)

Program Track Chair

Brian Jet-Fei Wong, Beckman Laser Institute and Medical Clinic (United States)

\section{Conference Chairs}

David H. Kessel, Wayne State University School of Medicine (United States)

Tayyaba Hasan, Massachusetts General Hospital (United States)

\section{Conference Program Committee}

Charles J. Gomer, Children's Hospital Los Angeles (United States)

Nancy L. Oleinick, Case Western Reserve University (United States)

Ravindra K. Pandey, Roswell Park Cancer Institute (United States)

Brian W. Pogue, Thayer School of Engineering at Dartmouth (United States)

Kenneth K. Wang M.D., Mayo Clinic (United States)

Session Chairs

1 Photodynamic Therapy I

David H. Kessel, Wayne State University School of Medicine (United States)

2 Photodynamic Therapy II

Imran Rizvi, Massachusetts General Hospital (United States)

3 Photodynamic Therapy III

Brian W. Pogue, Thayer School of Engineering at Dartmouth (United States)

4 Photodynamic Therapy IV

Jonathan P. Celli, University of Massachusetts Boston (United States) 
5 NIH Report

David H. Kessel, Wayne State University School of Medicine (United States)

6 Photodynamic Therapy $\mathrm{V}$

Keith Cengal, University of Pennsylvania (United States)

$7 \quad$ Photodynamic Therapy $\mathrm{VI}$

Timothy M. Baran, University of Rochester Medical Center (United States)

8 Photodynamic Therapy VII

Srivalleesha Mallidi, Harvard Medical School (United States)

9 Photodynamic Therapy VIII

Timothy C. Zhu, The University of Pennsylvania Health System (United States) 


\section{Introduction}

SPIE has been sponsoring conferences related to photodynamic therapy since 1987. These were initially organized by Thomas Dougherty, but more recently (since 2003) by David H. Kessel, with Tayyaba Hasan added in 2011 . We attempt to bring together a cross-section of major workers in the field along with new investigators that periodically appear. Contributions include both basic science and clinical applications.

PDT research was initially directed at finding out what malignant conditions could be treated and attempts at drug development. The early products tended to be somewhat non-specific and could result in persistent skin photosensitization. More recent photosensitizers have improved specificity, sometimes as a result of targeting via nanotechnology or immunologic processes. Light sources and dosimetry determination have also improved.

Several effects have served to limit the impact of PDT on health care. Some pharmaceutical organizations in the United States have not seen sufficient profits in the PDT field. Funding for basic and clinical research has remained flat, resulting in decreased support. It appears that more active programs are occurring in Europe and Asia, for a variety of reasons.

In spite of such difficulties, some of which have affected PDT since early days, the field does continue to progress. Examples of successful therapy for neoplastic disease and other indications continue to be demonstrated. The efficacy of this form of therapy in some cases remains superior to all other options.

David H. Kessel

Tayyaba Hasan 
Proc. of SPIE Vol. $9308930801-10$

Downloaded From: https://www.spiedigitallibrary.org/conference-proceedings-of-spie on 26 Apr 2023 Terms of Use: https://www.spiedigitallibrary.org/terms-of-use 